DOI 10.17234/SocEkol.29.2.5

UDK 005.35:338.45](497.5)

659.4:338.45](497.5)

$338.45: 174](497.5)$

366.12:644](497.5)
Prethodno priopćenje

Primljeno: 27. 11. 2019.

Prihvaćeno: 12.07. 2020.

\title{
NAJZNAČAJNIJI ELEMENTI DRUŠTVENO ODGOVORNOG POSLOVANJA PREHRAMBENIH KOMPANIJA U REPUBLICI HRVATSKOJ
}

\author{
Romana Zlatar-Vulić
}

\author{
„Podravka“ d.d. \\ Ante Starčevića 32, 48000 Koprivnica \\ e-mail: romana.zlatar@gmail.com
}

\section{Sažetak:}

Hrvatska bilježi kontinuirani rast interesa za primjenu koncepta "društveno odgovornog poslovanja“ (DOP-a). Koncept društveno odgovornog poslovanja uključuje ekonomsku, ekološku i socijalnu odgovornost $i$ kao takav prepoznat je kao važan čimbenik sve većeg broja poslovnih subjekata. Bez obzira na područje djelatnosti hrvatske kompanije prepoznale su važnost uvodenja društveno odgovornog poslovanja u vlastitu strategiju djelovanja, a s ciljem formiranja održivog poslovanja i održive zajednice. Društveno odgovorno poslovanje prepoznali su i potrošači te se i kod njih bilježi sve veći interes za društvenu odgovornost poslovnih subjekata. Dosadašnja se istraživanja nisu bavila društveno odgovornim poslovanjem prehrambenih kompanija kako ga razumiju hrvatski potrošači. Stoga, ovaj rad nastoji pružiti uvid u društveno odgovorno poslovanja prehrambenih kompanija kroz prizmu hrvatskih potrošača, kao i informacije o tome koje je područje unutar društveno odgovornog poslovanja najvažnije za potrošače prilikom kupnje prehrambenih proizvoda. Istraživanje DOP-a te ponašanja potrošača u procesu kupnje prehrambenih proizvoda obuhvatilo je 105 ispitanika pretežno s područja sjeverozapadne Hrvatske. Istraživanje je provedeno internetskim anketnim upitnikom u listopadu i studenom 2017. Dobiveni rezultati statistički su obradeni. Rezultati istraživanja pokazali su da potrošači prilikom kupnje prehrambenih proizvoda, najmanji značaj pridaju kontinuiranom pozitivnom financijskom poslovanju prehrambenih kompanija dok najveći značaj pridaju društveno odgovornim aktivnostima kompanija, jer tako stječu osjećaj vlastitog doprinosa pozitivnom aspektu DOP-a, odgovornom ponašanju kompanija prema okolišu i prirodnim resursima te brizi kompanija za globalni okoliš. Istraživanje je pokazalo da postoji statistički značajna razlika sobzirom na dob $i$ stručnu spremu potrošača kada se radi o utjecaju brige kompanije za globalni okoliš na odluku o kupnji. Briga za globalni okoliš najvažnija je potrošačima srednje životne dobi te onima koji imaju završsen preddiplomski ili diplomski studij.

Ključne riječi: društveno odgovorno poslovanje, odluka o kupnji, prehrambeni proizvodi

\section{UVOD}

Društveno odgovorno poslovanje (DOP) postalo je vrlo aktualna tema suvremenog doba. Iako se široko raspravlja o njegovim definicijama, načelima i učincima koje ima na kompanije i društvo, neosporno je da DOP postaje važan segment poslovanja i poslovne uspješnosti (Vrdoljak Raguž, 2014; Matešić i sur., 2015). Iz perspektive hijerarhijske di- 
menzije DOP-a navode se sljedeće društvene odgovornosti (Buble, 2009; Carroll, 1991; Cerjan-Letica, 2010): ekonomska, pravna, etička i filantropska odgovornost. Ekonomska odgovornost odnosi se na očekivanje kompanije da maksimizira svoju zaradu po dionici (McWilliams i Siegel, 2001), pravna odgovornost uključuje obvezu provođenja zakona i propisa (Fisher, 2004), etička odgovornost podrazumijeva vrijednosti, pravila i uvjerenja s moralnog i etičkog aspekta (Donaldson i Preston, 1995), dok se filantropska odgovornost odnosi na dobrotvorna očekivanja društva od kompanije (Kotler i Lee, 2009). Temeljem ovih četiriju komponenti, društveno odgovorna kompanija trebala bi težiti stvaranju profita, poslovati shodno zakonu, biti etična i biti dobar korporativni i građanin.

Tematika percepcije potrošača $s$ aspekta njihove informiranosti o DOP-u prehrambenih kompanija, kao i utjecaj tih informacija na kupnju, izuzetno je zanimljiva i aktualna. Istraživanja o DOP-u s naglaskom na prehrambeni sektor u Republici Hrvatskoj prilično su ograničena i nema ih mnogo, što ostavlja prostor prilici za dodatno istraživanje ove teme. Stoga je provedeno istraživanje o utjecaju DOP-a prehrambenih kompanija na potrošače prehrambenih proizvoda u Republici Hrvatskoj s ciljem utvrđivanja najvažnijih elementa DOP-a prehrambenih kompanija kroz prizmu hrvatskih potrošača prilikom razmatranja i odluke o kupnji prehrambenih proizvoda.

\section{KONCEPT DRUŠTVENO ODGOVORNOG POSLOVANJA}

\subsection{Pojam društveno odgovornog poslovanja}

Koncept društveno odgovornog poslovanja (engl. Corporate Social Responsibility - CSR) pojavio se u Sjedinjenim Američkim Državama, a i većina studija koja se bavila tom temom provedena je ondje. Brojne su akademske publikacije koje analiziraju koncept DOP-a iz različitih perspektiva, poput temeljnih poslovnih pristupa ili javnih doprinosa kompanija. Ne postoji podatak o vremenu nastanka DOP-a (Europska komisija, 2001), ali jedan od najranijih pojavnih oblika DOP-a je tzv. „korporacijska filantropija“ (Bagić i sur., 2004), naziv koji i danas prevladava u Sjevernoj Americi.

Izraz DOP koristi se već desetljećima, ali kako se razvijao, prilagođen je najzahtjevnijim uvjetima na tržištima, onima koje postavljaju dioničari i društvo općenito. DOP je postao prioritet za mnoge kompanije (Poljak i sur., 2013) širom svijeta u mnogim različitim sektorima i industrijama koje pokušavaju umanjiti svoj mogući negativni utjecaj na društvo, na vlastitu inicijativu ili pod pritiskom vlada, nevladinih organizacija (NVO) i ostalih dionika1. Te industrije uključuju automobilsku industriju, s markama kao što su Mitsubishi i Ford, naftnu industriju (pod visokim pritiscima nevladinih organizacija), industriju alkoholnih pića (na primjer, Bacardi i njegov jasni fokus na održivost svojim izvješćem o DOP-u „naš je duh jasan“), modnu industriju (C\&A i njegov logotip "Cradle to Cradle Certified ${ }^{\mathrm{T} * *}$ "ili H\&M i njegova kolekcija "Conscious Exclusive“

1 Dionici ili interesno utjecajne skupine koje utječu, ili su pod utjecajem odluka i aktivnosti kompanija (Bačun i sur., 2012). 
(„TENCEL ${ }^{\mathrm{TM}}$ and REFIBRA ${ }^{\mathrm{Tw}}$ ), financijski sektor (ulaganje Citigroupa u iznosu od 50 milijardi dolara s ciljem smanjenja ugljičnog dioksida), tehnološku industriju (Nokia i njezini zeleni telefoni) i prehrambenu industriju (Nestlé ili Coca Cola i njezin savez sa Svjetskom organizacijom za zaštitu prirode (WWF) (Reichert, 2016).

Provođenje aktivnosti DOP-a, kompanijama nudi niz koristi, kao na primjer, jačanje tržišne pozicije, konkurentnosti i pozicije marke, jačanje lojalnosti potrošača, povećanje zadovoljstva radnika, itd., dok s druge strane postoje pozitivni aspekti kompanija koje provode aktivnosti DOP-a i pružaju svojevrsne koristi zajednici i društvu (Glavočević i Radman-Peša, 2013).

DOP je od velike važnosti za industriju hrane i pića koja „zadovoljava“ osnovne ljudske potrebe te ima snažan utjecaj na javno zdravlje (Boccia i Covino, 2018). Inicijative DOP-a postale su temeljni dio poslovnih aktivnosti u industriji hrane i pića, posebno za kompanije visokih vrijednosti potrošačkih marki (Boumediene i Houda, 2018).

\subsection{Društveno odgovorno poslovanje prehrambenih kompanija}

Povijesni razvoj definicije društveno odgovornog poslovanja počinje 30-ih i 40-ih godina prošlog stoljeća kada je ovaj pojam bio poznat kao društvena odgovornost, a odnosio se na spremnost gospodarstvenika za korištenje resursa za šire društvene ciljeve (Carroll, 1999). Definicija se tijekom vremena razvijala baš kao i predmetni koncept. Razvojem poduzetništva, pojam je 50-ih godina poznat kao društveno odgovorno poslovanje. Koncepcija DOP-a prolazila je faze od prisnosti odnosa između korporacije i društva do neizravnog povezivanja određenih dobrovoljnih organizacija s kompanijama, dok se 90-ih godina koncept DOP-a značajno usmjerio na alternativne teme kao što su teorija dionika, teorija poslovne etike i korporativno građanstvo (Carroll, 1999).

U današnje vrijeme, uobičajena je definicija da je koncept DOP-a koji kompanije primjenjuju uključujući društvene i ekološke probleme u svoje poslovanje i svoju interakciju s dionicima (zaposlenicima, kupcima, dioničarima, investitorima, lokalnim zajednicama ili vladom) na dobrovoljnoj osnovi (Reichert, 2016). Stoga je ovaj „pojam“ usko povezan s načelom održivosti, koje tvrdi da kompanije trebaju donositi odluke temeljem neposrednih i dugoročnih socijalnih i ekoloških posljedica svojih aktivnosti, osim uobičajenih ciljeva ostvarivanja ekonomskih koristi (Cragg i sur., 2017).

Prema Bagić i suradnicima (2006), koncept DOP-a može se opisati kroz više pojmova: održivi razvoj, korporativno građanstvo, etično poslovanje..., koji se koriste kao „sinonimi“, budući da su temeljna načela ista i međusobno povezana. Unatoč izuzetno velikom broju terminologija, koncepcija i definicija, zajedničko im je temeljno značenje kao i cilj DOP-a, a to je stvaranje visokih životnih standarda za dionike izvan i unutar poduzeća uz istovremeno očuvanje profitabilnosti (Hopkins, 2006).

Većina definicija DOP-a uključuje aspekt doprinosa kvaliteti okoliša. Negativni utjecaj na okoliš kao što su zagađenja vode, zraka i tla, krčenja šuma, neodgovornog gospodarenja otpadom itd. (Šiljković, 2000), između ostalih, ima i prehrambena industrija. Iz toga razloga, dionici prehrambenih kompanija od njih zahtijevaju da se u svojim procesima bave problemima zaštite okoliša (Cartland, 2015). Proizvođači hrane trebali bi 
kupcima pružiti ne samo ekološki prihvatljive proizvode, već im i pokazati da vode brigu o okolišu (Daskalopoulou, 2019; Cartland, 2015). Kao što praksa pokazuje, mnoge vodeće prehrambene kompanije kao što su Starbucks, McDonald's i Pizza Hut usvojile su programe za smanjenje negativnog utjecaja na okoliš smanjenjem potrošnje energije i vode, izgradnjom zelenijih prodavaonica i poboljšanjem ambalaže hrane većim stupnjem upotrebe materijala za recikliranje (Pathak, 2011).

Prema temeljnim aspektima DOP-a, kompanije prehrambene industrije trebale bi biti društveno odgovorne prema širokom spektru dionika (Heikkurinen i Forsman-Hugg, 2011). Što se tiče društvenog utjecaja prehrambene industrije, potrebno je uzeti u obzir opsežniji dijapazon aktivnosti, s obzirom da su krajnji kupci u takvoj industriji opća (potrošačka) javnost (McIntyre i sur., 2018).

Nadovezujući se na sve navedeno, može se ustvrditi da je poljoprivredna proizvodnja ujedno i „uzrok i žrtva“ onečišćenja pa je implementacija i primjena DOP-a u prehrambenim kompanijama nužna i s aspekta koristi samih kompanija, a također i s aspekta doprinosa za društvenu zajednicu.

Kada razmatramo percepciju potrošača u odnosu na DOP prehrambenih kompanija, valja naglasiti sve veći interes potrošača za ovu temu te $s$ tim u vezi, različite aspekte ponašanja potrošača u svezi odgovornog poslovanja prehrambenih kompanija. Istraživanje Lombardija i suradnika (2015) provedeno na uzorku od 236 talijanskih potrošača, pokazalo je da su potrošači spremni platiti više za prehrambene proizvode kompanija koje provode DOP. Nije ustanovljena povezanost socijalno-ekonomskih karakteristika potrošača u smislu „voljnosti za platiti“ (engl. willingness to pay - WTP) tzv. „premijsku cijenu“ za proizvode kompanija koje provode DOP u sklopu etičkih načela, već je ustanovljena povezanost percepcije potrošača s pojedinačnim vrijednostima kompanije (npr. dobročinstvo, univerzalnost, hedonizam, postignuće, snaga, sigurnost, tradicija). Ujedno je naglašeno da se potrošačka „voljnost na kupnju“ u smislu strategije implementacije DOP-a temelji na tzv. „uvjetnoj procjeni“ budući da se podaci razlikuju ovisno o slučaju koji se razmatra. Također je utvrđeno da osjetljivost potrošača na DOP može rezultirati, ako ne budu primijenjene društveno odgovorne strategije, „bojkotiranjem“ proizvoda tih kompanija što bi utjecalo na njihovu prodaju i reputaciju (Lombardi i sur., 2015).

U vezi s primjenom DOP-a u Republici Hrvatskoj, od prve konferencije o DOP-u „Agenda 2005“ krajem 2004. do danas, važnost i utjecaj primjene DOP-a u Republici Hrvatskoj pojačano se razvijaju i organiziraju mnogi projekti i edukacije o njegovoj primjeni u poslovanju. Prema podacima provedenog istraživanja DOP-a u Hrvatskoj (Quien, 2012), pet kompanija od ukupno trinaest dobilo je ocjene pet i četiri s obzirom na razrađenost DOP-a, što pokazuje da Republika Hrvatska ima primjera dobre prakse koji mogu biti inspiracija i poticaj drugima.

Nadovezujući se na spoznaju da DOP uključuje zaštitu okoliša, ljudskih prava, potrošača, zdravlja, sigurnosti, upravljanje ljudskim potencijalima, prava zaposlenika, odnose $s$ dobavljačima, korporativno upravljanje, prava dionika, razvoj društvene zajednice i mnoge druge (Matešić i sur., 2015), provedenim istraživanjem nastojalo se utvrditi koji su elementi DOP-a prehrambenih kompanija u Republici Hrvatskoj, s aspekta odluke 
o kupnji prehrambenih proizvoda, potrošačima najznačajniji te postoji li razlika u smislu demografskih obilježja potrošača u kontekstu percepcije i stavova u vezi s njihovim odabirom i odlukama o kupnji prehrambenih proizvoda.

\section{EMPIRIJSKO ISTRAŽIVANJE}

U ovom dijelu rada, iznijeti su podaci provedenog istraživanja o društveno odgovornom poslovanju prehrambenih kompanija na području Republike Hrvatske.

Definirani su sljedeći ciljevi istraživanja:

- utvrditi koje elemente DOP-a prehrambenih kompanija u RH potrošači smatraju najznačajnijim prilikom kupovine prehrambenih proizvoda,

- postoji li razlika u strukturi potrošača u kontekstu percepcije i stavova u vezi s njihovim odabirom i odlukama o kupnji prehrambenih proizvoda.

S obzirom na to da kupnja prehrambenih proizvoda spada u tzv. „rutinsku“, svakodnevnu, učestalu kupnju već poznatih kategorija i marki proizvoda, tj. kada osoba kupuje po navici (Kesić, 2006), željelo se istražiti:

- postoje li razlike između potrošača, ako se izdvoje tri sociodemografska obilježja: spol, dob i stručna sprema, prilikom odabira prehrambenih proizvoda ovisno o percepciji ispitanika o DOP-u temeljem 13 definiranih tvrdnji,

- postoje li razlike između potrošača, u vezi s utjecajem izdvojenih dviju sociodemografskih karakteristika: spol i stručna sprema u odnosu na prihvaćanje triju tvrdnji o DOP-u koje najbolje opisuju stav potrošača.

Istraživanjem društveno odgovornog poslovanja te ponašanja potrošača u procesu kupnje prehrambenih proizvoda obuhvaćeno je 105 ispitanika s područja Republike $\mathrm{Hr}$ vatske. Korišten je prigodni uzorak $(\mathrm{N}=105)$, a anketno istraživanje provedeno je u listopadu i studenom 2017. Ispitanici su odgovorili na pitanja u upitnicima koji su imali sljedeće tri skupine pitanja:

- opći podaci o ispitanicima (spol, dob, stručna sprema i sl. sociodemografska obilježja):

- 18 pitanja o DOP-u (pitanja označena s A1 do A18)

- 16 pitanja o ponašanju potrošača u procesu kupnje prehrambenih proizvoda (pitanja označena s B1 do B16).

Pitanja u upitnicima bila su zatvorenog tipa, isključivo s jednim mogućim odgovorom od njih više ponuđenih. Svi upitnici popunjavali su se internetskim putem na aplikaciji Google. Iz dobivene datoteke Excel podaci su konvertirani u datoteku SPSS. Na osnovu datoteke SPSS izvedene su statističke analize (programom SPSS Statistics for Windows, verzija 17.0), a grafički prikazi izrađeni su pomoću Microsoft Excela 2010.

U ovom istraživanju s 3 grupe podataka (opći, A1 do A18 i B1 do B16), razmatrana su samo tri opća podatka (spol, dob i stručna sprema) te 13 pitanja koja se odnose na ponašanje potrošača u procesu kupnje prehrambenih proizvoda (pitanja B4 do B16). Korištene su sljedeće metode statističke analize:

a) deskriptivne metode (tablični i grafički prikazi, postoci, srednje vrijednosti, mjere disperzije, koeficijenti korelacije ranga); 
b) inferencijalne metode (Kolmogorov-Smirnovljev test normalnosti distribucije, hi-kvadrat test, Mann-Whitneyev U test, Kruskal-Wallisov H test, t-test i F-test razlike aritmetičkih sredina, dvofaktorska analiza varijance);

c) multivarijatne metode (faktorska analiza, analiza pouzdanosti i klaster analiza).

Zaključci u vezi s razlikama i povezanosti među varijablama donošeni su na nivou signifikantnosti od 0,05 odnosno uz pouzdanost od 95\%.

$\mathrm{U}$ radu su postavljene dvije hipoteze čija je istinitost provjerena odgovarajućim testovima:

H1: Anketirani potrošači različitog spola, različite dobi odnosno različite stručne spreme statistički se značajno ne razlikuju s obzirom na prihvaćanje svih 13 tvrdnji o DOP-u. H2: Briga o globalnoj zaštiti okoliša kao jednoj od glavnih odrednica pojma društveno odgovornog poslovanja statistički se značajno ne razlikuje kod potrošača prehrambenih proizvoda koji su različite dobi te različite stručne spreme.

Struktura ispitanika prema spolu, dobi i prema stručnoj spremi navedena je u Tablici 1.

Tablica 1. Struktura anketiranih potrošača prema spolu, dobi i stručnoj spremi

\begin{tabular}{|c|c|c|c|}
\hline & Kategorije ispitanika & $\begin{array}{c}\mathrm{N} \\
\text { ispitanika }\end{array}$ & $\begin{array}{c}\% \\
\text { ispitanika }\end{array}$ \\
\hline \multirow{2}{*}{ Spol: } & Muški & 27 & 26 \\
\hline & Ženski & 78 & 74 \\
\hline \multicolumn{2}{|r|}{ Ukupno po spolu } & 105 & 100 \\
\hline \multirow{6}{*}{ Dob: } & Do $25 \mathrm{~g}$ & 3 & 3 \\
\hline & $26-35$ & 24 & 23 \\
\hline & $36-45$ & 27 & 25 \\
\hline & $46-55$ & 36 & 34 \\
\hline & $56-65$ & 10 & 10 \\
\hline & $66+$ & 5 & 5 \\
\hline \multicolumn{2}{|r|}{ Ukupno po dobi } & 105 & 100 \\
\hline \multirow{5}{*}{ Stručna sprema: } & OŠ & 3 & 3 \\
\hline & SŠ (4 godine) & 24 & 23 \\
\hline & Dodiplomski studij & 20 & 19 \\
\hline & Diplomski studij & 48 & 45 \\
\hline & Poslijediplomski i doktorski studij & 10 & 10 \\
\hline \multicolumn{2}{|r|}{ Ukupno po stručnoj spremi } & 105 & 100 \\
\hline
\end{tabular}

Struktura ispitanika ide u prilog ženskom spolu (74\%), srednje dobi (između 46 i 55 godina, 34\%) te sa završenim diplomskim studijem (45\%). U nastavku su prezentirane apsolutne i relativne frekvencije dobivene na seriju tvrdnji o DOP-u (Tablica 2) koje su 
označene s B4 do B16. Sve te tvrdnje nudile su odgovore na Likertovoj skali od 1 do 5 , gdje su s vrijednostima 1, 2, 3, 4 i 5 označeni sljedeći odgovori:

$1=$ izrazito se ne slažem

$2=$ ne slažem se

$3=$ niti se slažem niti se ne slažem

4 = slažem se

5 = izrazito se slažem

U Tablici 3 su na osnovu frekvencija iz Tablice 2 prezentirani izračunati deskriptivni pokazatelji: medijalne vrijednosti, aritmetičke sredine, standardne devijacije i koeficijenti varijacije.

Tablica 2. Anketirani ispitanici prema učestalosti prihvaćanja pojedinih tvrdnji*

\begin{tabular}{|c|c|c|c|c|c|c|c|}
\hline $\begin{array}{l}\frac{\pi}{\tilde{J}} \\
\text { ปี }\end{array}$ & $\begin{array}{l}\text { Varijabla (tvrdnja) } \\
\text { Svakom retku u tablici prethodi sljedeći tekst: } \\
\text { „Kod odluke o odabiru i kupnji prehrambenog } \\
\text { proizvoda, biram proizvođače...“ }\end{array}$ & 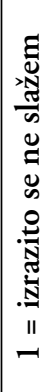 & 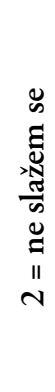 & 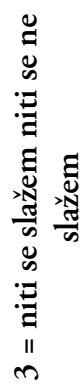 & 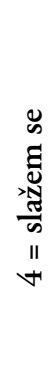 & 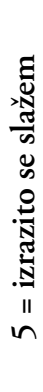 & 苛 \\
\hline B4 & ...koji u svom poslovanju primjenjuju elemente DOP-a & 1 & 20 & 52 & 31 & 1 & 105 \\
\hline B5 & ...koji vode brigu o ljudskim resursima & 1 & 23 & 41 & 40 & - & 105 \\
\hline B6 & ...koji zapošljavaju lokalno stanovništvo & 4 & 16 & 35 & 44 & 6 & 105 \\
\hline B7 & ...koji odgovorno utječe na okoliš i prirod. resurse & 1 & 9 & 35 & 52 & 8 & 105 \\
\hline B8 & ...koji su nepristrani i korektni s poslovnim partnerima & 1 & 17 & 37 & 46 & 4 & 105 \\
\hline B9 & ...koji brinu o poštivanju ljudskih prava & 1 & 12 & 33 & 53 & 6 & 105 \\
\hline B10 & $\begin{array}{l}\text {... koji brinu o globalnoj zaštiti okoliša (odgovorno } \\
\text { gospodarenje otpadom,...) }\end{array}$ & 1 & 8 & 36 & 52 & 8 & 105 \\
\hline B11 & $\begin{array}{l}\text {...koji primjenjuju principe DOP-a - dokaz izbora } \\
\text { kvalitetnog proizvoda }\end{array}$ & - & 16 & 50 & 37 & 2 & 105 \\
\hline B12 & $\begin{array}{l}\text {...koji provode aktivnosti DOP-a - osjećaj osobnog } \\
\text { doprinosa potrošača pozitivnom aspektu DOP-a }\end{array}$ & 1 & 9 & 33 & 57 & 5 & 105 \\
\hline B13 & ...koji financijski kontinuirano pozitivno posluju & 3 & 45 & 47 & 10 & - & 105 \\
\hline B14 & ...koji su renomirani i s pozitivnim publicitetom & - & 17 & 41 & 45 & 2 & 105 \\
\hline B15 & ...koji imaju pozitivan imidž & - & 15 & 30 & 55 & 5 & 105 \\
\hline $\mathrm{B} 16$ & ...koji su poželjan poslodavac & - & 21 & 46 & 35 & 3 & 105 \\
\hline
\end{tabular}

* U svakom retku tablice podebljano je otisnuta najveća apsolutna frekvencija

Najveće frekvencije u Tablici 2 su kod vrijednosti 3 („niti se slažem niti se ne slažem“) i kod vrijednosti 4 (,slažem se“). Prema tome, anketirani potrošači su kod dijela tvrdnji izrazili indiferentnost (kod pet tvrdnji), ili su izrazili prihvaćanje tih tvrdnji kao točnih 
(kod osam tvrdnji). Precizniji izraz manjeg ili većeg prihvaćanja tvrdnji ispitanika vidljiv je iz vrijednosti medijana, a još bolje iz aritmetičkih sredina u Tablici 3 budući da su one izražene na dvije decimale.

Tablica 3. Deskriptivni pokazatelji po pojedinim turdnjama

\begin{tabular}{|c|c|c|c|c|c|}
\hline$\frac{\pi}{\tilde{3}}$ & $\begin{array}{l}\text { Varijabla (tvrdnja) } \\
\text { Svakom retku u tablici prethodi sljedeći tekst: } \\
\text { „Kod odluke o odabiru i kupnji prehrambenog } \\
\text { proizvoda biram proizvođače...““ }\end{array}$ & 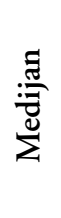 & 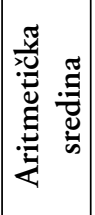 & 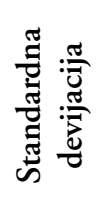 & 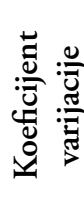 \\
\hline B4 & ...koji u svom poslovanju primjenjuju elemente DOP-a & 3 & 3,10 & 0,746 & 24 \\
\hline B5 & ...koji vode brigu o ljudskim resursima & 3 & 3,14 & 0,790 & 25 \\
\hline B6 & ... koji zapošljavaju lokalno stanovništvo & 3 & 3,30 & 0,932 & 28 \\
\hline B7 & ...koji odgovorno utječe na okoliš i prirodne resurse & 4 & 3,54 & 0,797 & 23 \\
\hline B8 & ...koji su nepristrani i korektni s poslovnim partnerima & 3 & 3,33 & 0,828 & 25 \\
\hline B9 & ...koji brinu o poštivanju ljudskih prava & 4 & 3,49 & 0,810 & 23 \\
\hline B10 & $\begin{array}{l}\text {...koji brinu o globalnoj zaštiti okoliša (odgovorno } \\
\text { gospodarenje otpadom,...) }\end{array}$ & 4 & 3,55 & 0,784 & 22 \\
\hline B11 & $\begin{array}{l}\text {...koji primjenjuju principe DOP-a - dokaz izbora } \\
\text { kvalitetnog proizvoda }\end{array}$ & 3 & 3,24 & 0,728 & 22 \\
\hline B12 & $\begin{array}{l}\text {...koji provode aktivnosti DOP-a - osjećaj osobnog } \\
\text { doprinosa pozitivnom aspektu DOP-a }\end{array}$ & 4 & 3,53 & 0,760 & 22 \\
\hline $\mathrm{B} 13$ & ...koji financijski kontinuirano pozitivno posluju & 3 & 2,61 & 0,700 & 27 \\
\hline B14 & ...koji su renomirani is pozitivnim publicitetom & 3 & 3,30 & 0,761 & 23 \\
\hline B15 & ...koji imaju pozitivan imidž & 4 & 3,48 & 0,798 & 23 \\
\hline B16 & ...koji su poželjan poslodavac & 3 & 3,19 & 0,786 & 25 \\
\hline
\end{tabular}

Najmanji značaj ispitanici pridaju kontinuiranom pozitivnom financijskom poslovanju (tvrdnja B13) budući da je kod te tvrdnje aritmetička sredina najmanja $(2,61)$. Najveći značaj ispitanici pridaju trima tvrdnjama: B12, B7 i B10. Za te tvrdnje su aritmetičke sredine gotovo identične (iznose 3,53; 3,54 i 3,55).

Inferencijalne metode statističke analize provedene su u nekoliko skupina.

Prva skupina analiza odnose se na netom spomenute tri tvrdnje koje su potrošači najviše prihvatili kao točne. One su stoga posebno interesantne za detaljniju analizu budući da ih potrošači najviše prihvaćaju. To su tvrdnje B7, B10 i B12 u kojima se tvrdi:

a) da potrošači odabiru prehrambene proizvode onih proizvođača koji odgovorno utječu na okoliš i prirodne resurse (B7);

b) da potrošači odabiru prehrambene proizvode onih proizvođača koji brinu o globalnoj zaštiti okoliša (B10); 
c) da potrošači odabiru prehrambene proizvode onih proizvođača koji provode aktivnosti DOP-a jer tako stječu osjećaj osobnog doprinosa pozitivnom aspektu DOP-a (B12). Za svaku je od tih tvrdnji pomoću Kolmogorov-Smirnovljevog testa provjerena normalnost (Tablica 4).

Tablica 4. Rezultati provjere normalnosti raspodjele kod tri ordinalne varijable

\begin{tabular}{|c|l|c|c|c|c|}
\hline Rbr. & \multicolumn{1}{|c|}{ Varijable za koje je provedeno testiranje } & $\mathbf{N}$ & $\mathbf{z}^{*}$ & $\mathbf{p}^{* *}$ & $\begin{array}{c}\text { Distribucija } \\
\text { je približno } \\
\text { normalna }\end{array}$ \\
\hline 1. & $\begin{array}{l}\text { Biram proizvođače koji odgovorno utječu na } \\
\text { okoliš i prirodne resurse (B7) }\end{array}$ & 105 & 0,288 & $<0,001$ & ne \\
\hline 2. & $\begin{array}{l}\text { Biram proizvođače koji brinu o globalnoj } \\
\text { zaštiti okoliša (B10) }\end{array}$ & 105 & 0,287 & $<0,001$ & ne \\
\hline 3. & $\begin{array}{l}\text { Biram proizvođače koji provode aktivnosti } \\
\text { DOP-a (B12) }\end{array}$ & 105 & 0,321 & $<0,001$ & ne \\
\hline
\end{tabular}

$*_{\mathrm{z}}=$ testna vrijednost

$* * \mathrm{p}=$ vjerojatnost da je distribucija normalnog oblika

Rezultatima provjere $(\mathrm{p}<0,001)$ utvrđeno je da se ne može prihvatiti pretpostavka o njihovoj normalnosti čime je daljnja njihova analiza ograničena samo na neparametrijske metode.

Nakon toga je provedeno devet hi-kvadrat testova kako bi se utvrdilo:

a) ima li povezanosti između spola i prihvaćanja svake pojedine tvrdnje (B7, B10, B12);

b) ima li povezanosti između dobi i prihvaćanja svake pojedine tvrdnje (B7, B10, B12) te

c) ima li povezanosti između stručne spreme i prihvaćanje svake pojedine tvrdnje (B7, B10, B12).

U navedenim testovima dob je iskazana u tri grupe (mlađi s 18-35 g., srednji s 36-55 g. i stariji s 56 i više godina), kao i stručna sprema (OŠ i SŠ, dodiplomski i diplomski studij, postdiplomski i doktorski studij). Prihvaćanje tvrdnji B7, B10 i B12 također je iskazano u tri grupe kako bi se zadovoljili uvjeti za primjenu hi-kvadrat testa ( 1 i 2 = neprihvaćanje tvrdnje; 3 = indiferentan stav; 4 i 5 = prihvaćanje tvrdnje). Rezultati nakon provedenih devet hi-kvadrat testova su sljedeći:

a) ne postoji povezanost obilježja spola s prihvaćanjem bilo koje od tri tvrdnje ( $>00,05)$;

b) ne postoji povezanost dobi i prihvaćanja bilo koje od tri tvrdnje $(\mathrm{p}>0,05)$;

c) ne postoji povezanost stručne spreme i tvrdnji B7 i B12 ( $>0,05)$, dok između stručne spreme i tvrdnje $B 10$ postoji statistički značajna povezanost $\left(\chi^{2}=10,501\right.$; $\mathrm{df}=4 ; \mathrm{N}=105 \mathrm{p}=0,033)$.

Uvidom u kontingencijsku tabelu (Tablica 5) izračunato je da od 27 potrošača najniže stručne spreme njih $44 \%$ prihvaća tvrdnju $\mathrm{B} 10$, kao i da od 68 potrošača završenog dodiplomskog i diplomskog studija njih 62\% prihvaća tvrdnju B10 te da od 10 potrošača postdiplomskog i doktorskog studija njih $60 \%$ prihvaća tvrdnju B10. Prema tome, 
tvrdnju da potrošači odabiru prehrambene proizvode onih proizvođača koji brinu o globalnoj zaštiti okoliša manje prihvaćaju ispitanici kojima je stručna sprema niža, dok je više prihvaćaju ispitanici koji imaju višu stručnu spremu.

Tablica 5. Ispitanici prema stručnoj spremi i prema pribvaćanju tvrdnje da kod kupnje prehrambenih proizvoda biraju proizvođače koji brinu o globalnoj zaštiti okoliša (tvrdnja B10)

\begin{tabular}{|c|c|c|c|c|c|}
\hline Rbr. & Stručna sprema & $\begin{array}{c}\text { Neprihvatitelji } \\
\text { tvrdnji (1 i 2) }\end{array}$ & Neodlučni (3) & $\begin{array}{c}\text { Prihvatitelji } \\
\text { tvrdnji (4 i 5) }\end{array}$ & Ukupno \\
\hline 1. & OŠ i SŠ & 3 & 12 & 12 & 27 \\
\hline 2. & $\begin{array}{c}\text { Dodiplomski i diplomski } \\
\text { studij }\end{array}$ & 3 & 23 & 42 & 68 \\
\hline 3. & $\begin{array}{c}\text { Postdiplomski i } \\
\text { doktorski studij }\end{array}$ & 3 & 1 & 6 & 10 \\
\hline & Ukupno & 9 & 36 & 60 & 105 \\
\hline
\end{tabular}

Za analizirane tri tvrdnje izvedeni su još i neparametrijski testovi usporedbe medijana. Za usporedbu po spolu korišten je Mann-Whitneyev U test, dok je za usporedbu po dobi i stručnoj spremi korišten Kruskal-Wallisov $\mathrm{H}$ test. Prema tome, izvedena su tri U testa i šest H testova za koje su rezultati prezentirani u Tablicama 6, 7 i 8.

Tablica 6. Rezultati usporedbe medijana za tvrdnju B7 (,Biram proizvođača prehrambenih proizvoda koji odgovorno utječe na okoliš i prirodne resurse") pomoću MannWhitneyevog U testa (za varijablu spols dvije kategorije) i Kruskal-Wallisovog $H$ testa (za varijable s tri kategorije)

\begin{tabular}{|c|c|c|c|c|c|c|c|}
\hline Rbr. & $\begin{array}{c}\text { Testna } \\
\text { (nezavisna) } \\
\text { varijabla }\end{array}$ & $\begin{array}{l}\text { Podgrupa } \\
\text { ispitanika }\end{array}$ & $\begin{array}{l}\text { Broj } \\
\text { ispit. }\end{array}$ & $\begin{array}{l}\text { Sredine } \\
\text { rangova }\end{array}$ & $\mathrm{U} / \mathrm{H}$ & $\mathrm{z} / \mathrm{df}^{*}$ & $\mathrm{p}^{* *}$ \\
\hline \multirow{2}{*}{1.} & \multirow{2}{*}{ Spol } & Muški & 27 & 52,81 & & & \\
\hline & & Ženski & 78 & 53,06 & $\mathrm{U}=1048$ & $z=-0,042$ & 0,967 \\
\hline \multirow{3}{*}{2.} & \multirow{3}{*}{ Dob } & Mlađi & 27 & 47,54 & & & \\
\hline & & Srednji & 63 & 53,00 & & & \\
\hline & & Stariji & 15 & 62,83 & $\mathrm{H}=3,136$ & $\mathrm{df}=2$ & 0,208 \\
\hline \multirow{3}{*}{3.} & \multirow{3}{*}{ Stručna sprema } & OŠ i SS & 27 & 50,13 & & & \\
\hline & & $\begin{array}{c}\text { Dodipl. i } \\
\text { dipl. studij }\end{array}$ & 68 & 54,29 & & & \\
\hline & & $\begin{array}{l}\text { Postdipl. i } \\
\text { dokt. studij }\end{array}$ & 10 & 52,00 & $\mathrm{H}=0,480$ & $\mathrm{df}=2$ & 0,787 \\
\hline
\end{tabular}

$* \mathrm{df}=$ broj stupnjeva slobode

$* * \mathrm{p}=$ statistička značajnost (signifikantnost), tj. rizik pogrešnog zaključka (vjerojatnost odbacivanja istinite nulte hipoteze o nepostojanju statistički značajnih razlika između aritmetičkih sredina). 
Tablica 7. Rezultati usporedbe medijana za tvrdnju B10 (,Biram proizvođača prehrambenih proizvoda koji brine o globalnoj zaštiti okoliša") pomoću Mann-Whitneyevog $U$ testa (za varijablu spol s dvije kategorije) i Kruskal-Wallisovog $H$ testa ( $z a$ varijable stri kategorije)

\begin{tabular}{|c|c|c|c|c|c|c|c|}
\hline Rbr. & $\begin{array}{c}\text { Testna } \\
\text { (nezavisna) } \\
\text { varijabla }\end{array}$ & $\begin{array}{l}\text { Podgrupa } \\
\text { ispitanika }\end{array}$ & $\begin{array}{l}\text { Broj } \\
\text { ispit. }\end{array}$ & $\begin{array}{l}\text { Sredine } \\
\text { rangova }\end{array}$ & $\mathrm{U} / \mathrm{H}$ & $\mathrm{z} / \mathrm{df}$ & $\mathrm{p}$ \\
\hline \multirow{2}{*}{1.} & \multirow{2}{*}{ Spol } & Muški & 27 & 52,61 & & & \\
\hline & & Ženski & 78 & 53,13 & $\mathrm{U}=1042,5$ & $\mathrm{z}=-0,088$ & 0,930 \\
\hline \multirow{3}{*}{2.} & \multirow{3}{*}{ Dob } & Mladi & 27 & 49,89 & & & \\
\hline & & Srednji & 63 & 55,02 & & & \\
\hline & & Stariji & 15 & 50,10 & $\mathrm{H}=0,901$ & $\mathrm{df}=2$ & 0,637 \\
\hline \multirow{3}{*}{3.} & \multirow{3}{*}{ Stručna sprema } & OŠ i SŠ & 27 & 46,33 & & & \\
\hline & & $\begin{array}{l}\text { Dodipl. i } \\
\text { dipl.studij }\end{array}$ & 68 & 56,15 & & & \\
\hline & & $\begin{array}{l}\text { Postdipl. i } \\
\text { dokt. studij }\end{array}$ & 10 & 49,55 & $\mathrm{H}=2,785$ & $\mathrm{df}=2$ & 0,248 \\
\hline
\end{tabular}

Tablica 8. Rezultati usporedbe medijana za tvrdnju B12 („Biram proizvođača prehrambenih proizvoda koji provode aktivnosti DOP-a") pomoću Mann-Whitneyevog U testa (za varijablu spol s dvije kategorije) i Kruskal-Wallisovog $H$ testa (za varijable s tri kategorije)

\begin{tabular}{|c|c|c|c|c|c|c|c|}
\hline Rbr. & $\begin{array}{c}\text { Testna } \\
\text { (nezavisna) } \\
\text { varijabla }\end{array}$ & $\begin{array}{l}\text { Podgrupa } \\
\text { ispitanika }\end{array}$ & $\begin{array}{l}\text { Broj } \\
\text { ispit. }\end{array}$ & $\begin{array}{l}\text { Sredine } \\
\text { rangova }\end{array}$ & $\mathrm{U} / \mathrm{H}$ & $\mathrm{z} / \mathrm{df}$ & $\mathrm{p}$ \\
\hline \multirow{2}{*}{1.} & \multirow{2}{*}{ Spol } & Muški & 27 & 50,20 & & & \\
\hline & & Ženski & 78 & 53,97 & $\mathrm{U}=977,5$ & $z=-0,634$ & 0,526 \\
\hline \multirow{3}{*}{2.} & \multirow{3}{*}{ Dob } & Mlađi & 27 & 47,65 & & & \\
\hline & & Srednji & 63 & 54,29 & & & \\
\hline & & Stariji & 15 & 57,23 & $\mathrm{H}=1,621$ & $\mathrm{df}=2$ & 0,445 \\
\hline \multirow{3}{*}{3.} & \multirow{3}{*}{ Stručna sprema } & OŠ i SSS & 27 & 53,56 & & & \\
\hline & & $\begin{array}{c}\text { Dodipl. i } \\
\text { dipl. studij }\end{array}$ & 68 & 54,06 & & & \\
\hline & & $\begin{array}{l}\text { Postdipl. i } \\
\text { dokt. studij }\end{array}$ & 10 & 44,30 & $\mathrm{H}=1,190$ & $\mathrm{df}=2$ & 0,552 \\
\hline
\end{tabular}

Svih devet testova (Tablice 6,7 i 8 ) pokazalo je da nema statistički značajnih razlika ( $\mathrm{p}>0,05)$ u prihvaćanju navedenih tvrdnji (B7, B10, B12) s obzirom na spol, dob odnosno stručnu spremu anketiranih potrošača.

Druga skupina analiza odnosi se na sve zavisne varijable (B4 do B16) koje su navedene u Tablicama 2 i 3 . U prvoj skupini analiza u kojima su obuhvaćene samo tri najprihva- 
ćenije tvrdnje (B7, B10 i B12) malo je utvrđenih statistički značajnih razlika, odnosno statistički značajnih povezanosti s nezavisnim varijablama (spol, dob, sprema). Stoga se kao daljnja mogućnost analize nametnula ideja o obuhvaćanju svih zavisnih varijabli, a ne samo onih koje su ispitanici u najvećoj mjeri prihvatili. Naime, odgovori svakog ispitanika na tvrdnje B4 do B16 zbrojeni su i podijeljeni s 13 čime je dobivena prosječna vrijednost prihvaćanja svih 13 tvrdnji. Navedeno je bilo moguće zahvaljujući tome što su sve te tvrdnje pozitivno formulirane, a odgovori su kodirani vrijednostima od 1 (,izrazito se ne slažem“) do 5 (,izrazito se slažem“). Na osnovu dobivenih prosjeka odgovora na tvrdnje B4 do B16 izračunati su deskriptivni pokazatelji (Tablica 9).

Tablica 9. Deskriptivni pokazatelji za prosjeke odgovora na turdnje B4 do B16

\begin{tabular}{|l|c|}
\hline \multicolumn{1}{|c|}{ Karakteristika distribucije } & Vrijednost \\
\hline Srednje vrijednosti: & \\
\hline Aritmetička sredina & 3,29 \\
\hline Medijan & 3,31 \\
\hline Mjere disperzije: & \\
\hline Najmanja vrijednost & 2,00 \\
\hline Najveća vrijednost & 4,46 \\
\hline Standardna devijacija & 0,525 \\
\hline Koeficijent varijacije & $16 \%$ \\
\hline Mjera asimetrije: & \\
\hline Skewness & $-0,50$ \\
\hline Mjera zaobljenosti: & \\
\hline Kurtosis & $-0,12$ \\
\hline Kolmogorov-Smirnovljev test: & \\
\hline z vrijednost u testu & 1,107 \\
\hline p vrijednost u testu & 0,173 \\
\hline Normalnost distribucije & da \\
\hline
\end{tabular}

Dakle, dobiveni prosjeci odgovora na tvrdnje B4 do B16 variraju između 2,00 i 4,46, a opći prosjek za sve ispitanike je 3,29, medijan je 3,31, standardna devijacija je 0,525 , a koeficijent varijacije niskih $16 \%$. Distribucija je tih prosjeka lijevostrano asimetrična $(S k=-0,50)$ dok je zaobljenost blizu zaobljenosti normalne krivulje $\left(\alpha_{4}=-0,12\right)$. Pomoću Kolmogorov-Smirnovljevog testa utvrđeno je da distribucija prosjeka sliči normalnoj distribuciji $(\mathrm{z}=1,107 ; \mathrm{p}=0,173)$.

Nadalje, proveden je t-test kako bi se utvrdilo razlikuju li se statistički značajno muški ispitanici od ženskih, s obzirom na prosječno prihvaćanje tvrdnji B4 do B16 (Tablica 10). Osim toga, provedene su dvije jednostavne analize varijance (F test) kako bi se utvrdilo postoje li statistički značajne razlike u navedenim prosjecima kod ispitanika različite dobi, odnosno ispitanika različitog obrazovanja. Rezultati ovih dvaju testova također se nalaze u Tablici 10. 
Tablica 10. Rezultati t-testa i F-testa (jednostavne analize varijance) kod usporedbe prosječnih odgovora na turdnje B4 do B16 ispitanika različitog spola, dobi i stručne spreme

\begin{tabular}{|c|c|c|c|c|c|c|c|}
\hline Rbr. & $\begin{array}{c}\text { Testna } \\
\text { (nezavisna) } \\
\text { varijabla }\end{array}$ & $\begin{array}{l}\text { Podgrupa } \\
\text { ispitanika }\end{array}$ & $\begin{array}{l}\text { Broj } \\
\text { ispit. }\end{array}$ & $\begin{array}{c}\text { Aritmetička } \\
\text { sredina }\end{array}$ & $\begin{array}{c}\text { Standardna } \\
\text { devijacija }\end{array}$ & $\mathrm{t} / \mathrm{F}^{*}$ & $\mathrm{p}$ \\
\hline \multirow{2}{*}{1.} & \multirow{2}{*}{ Spol } & Muški & 27 & 3,30 & 0,647 & & \\
\hline & & Ženski & 78 & 3,29 & 0,481 & $\mathrm{t}=0,061$ & 0,951 \\
\hline \multirow{3}{*}{2.} & \multirow{3}{*}{ Dob } & Mlađi & 27 & 3,13 & 0,481 & & \\
\hline & & Srednji & 63 & 3,34 & 0,545 & & \\
\hline & & Stariji & 15 & 3,41 & 0,475 & $\mathrm{~F}=1,941$ & 0,149 \\
\hline \multirow{3}{*}{3.} & \multirow{3}{*}{$\begin{array}{l}\text { Stručna } \\
\text { sprema }\end{array}$} & OŠ i ŠS & 27 & 3,38 & 0,573 & & \\
\hline & & $\begin{array}{c}\text { Dodipl. i } \\
\text { dipl. studij } \\
\end{array}$ & 68 & 3,28 & 0,481 & & \\
\hline & & $\begin{array}{l}\text { Postdipl. i } \\
\text { dokt. studij }\end{array}$ & 10 & 3,17 & 0,687 & $\mathrm{~F}=0,721$ & 0,489 \\
\hline
\end{tabular}

$*_{\mathrm{t}}=$ vrijednost $\mathrm{u} \mathrm{t}$-testu; $\mathrm{F}=$ vrijednost $\mathrm{u}$ jednofaktorskoj analizi varijance, univarijatnom $\mathrm{F}$ testu

Pomoću t-testa utvrđeno je da se ispitanici muškog spola u odnosu na ispitanike ženskog spola statistički značajno ne razlikuju po prosjecima prihvaćanja svih tvrdnji B4 do B16 ( $\mathrm{t}=0,061 ; \mathrm{p}=0,951)$. Nadalje, pomoću F-testa (jednostavna analiza varijance) utvrđeno je da se ispitanici triju dobnih skupina također statistički značajno ne razlikuju po prosjecima prihvaćanja navedenih tvrdnji $(\mathrm{F}=1,941 ; \mathrm{p}=0,149)$. Isto tako, među ispitanicima ne postoji statistički značajna razlika u prihvaćanju navedenih tvrdnji u odnosu na obilježja njihove stručne spreme ( $\mathrm{F}=0,721 ; \mathrm{p}=0,489)$.

Prva hipoteza glasi „Anketirani potrošači različitog spola, različite dobi odnosno različite stručne spreme statistički se značajno ne razlikuju s obzirom na prihvaćanje svih 13 tvrdnji o DOP-u“. Prema iznesenim je rezultatima navedena hipoteza potvrđena.

Treća skupina analiza odnosi se na tvrdnju B10 koja kaže da se kod odluke o odabiru i kupnji prehrambenog proizvoda biraju proizvođači koji brinu o globalnoj zaštiti okoliša. Naime, kada se spomene pojam DOP često nas to asocira na brigu o zaštiti okoliša. Stoga se može postaviti hipoteza $\mathrm{H} 2$.

Drug hipoteza glasi „Briga o globalnoj zaštiti okoliša kao jednoj od glavnih odrednica pojma društveno odgovornog poslovanja statistički se značajno ne razlikuje kod potrošača prehrambenih proizvoda koji su različite dobi te različite stručne spreme“. Hipoteza je provjerena pomoću dvofaktorske analize varijance (Two-way ANOVA) u kojoj su varijable imale sljedeći status:

- briga o globalnoj zaštiti okoliša (tvrdnja B10) $\rightarrow$ kvantitativna zavisna varijabla

- dob potrošača $\rightarrow$ kvalitativna nezavisna varijabla

- sprema potrošača $\rightarrow$ kvalitativna nezavisna varijabla.

Unatoč tome što tvrdnja B10 kao varijabla nije normalno distribuirana (u Kolmogorov-Smirnovljevom testu normalnosti dobiven je $\mathrm{z}=0,287$, a $\mathrm{p}<0,001$ kako je navedeno u Tablici 3), provedena je ova parametrijska metoda analize kako bi se provjerila istini- 
tost hipoteze H2. U Tablici 11 navedene su aritmetičke sredine za tvrdnju B10, dok je Tablica 12 standardna ANOVA tablica.

Tablica 11. Prosječne vrijednosti za tvrdnju o zaštiti okoliša anketiranih potrošača prehrambenih proizvoda (tvrdnja B10) sobzirom na njihovu dob i na njihovu stručnu spremu

\begin{tabular}{|l|c|c|c|c|}
\hline \multirow{2}{*}{ Dob } & \multicolumn{3}{|c|}{ Stručna sprema } & \multirow{2}{*}{ Ukupno } \\
\cline { 2 - 4 } & $\begin{array}{c}\text { Osnovna i srednja } \\
\text { škola }\end{array}$ & $\begin{array}{c}\text { Dodiplomski i } \\
\text { diplomski studij }\end{array}$ & $\begin{array}{c}\text { Postdiplomski i } \\
\text { doktorski studij }\end{array}$ & \\
\hline Mlađa & 2,71 & 3,83 & 3,50 & 3,52 \\
\hline Srednja & 3,65 & 3,55 & 3,83 & 3,60 \\
\hline Starija & 2,67 & 3,80 & 2,50 & 3,40 \\
\hline Ukupno & 3,30 & 3,66 & 3,50 & 3,55 \\
\hline
\end{tabular}

Tablica 12. Rezultati analize varijance (ANOVA) za tvrdnju o brizi za globalnu zaštitu okoliša kao zavisnom kvantitativnom varijablom

\begin{tabular}{|l|c|c|c|c|c|}
\hline Kvalitativna varijabla & Suma kvadrata & df & Sredine kvadrata & F & p \\
\hline Dob & 3,931 & 2 & 1,965 & 3,641 & 0,030 \\
\hline Stručna sprema & 6,991 & 2 & 3,496 & 6,477 & 0,002 \\
\hline Dob * sprema & 8,889 & 4 & 2,222 & 4,118 & 0,004 \\
\hline
\end{tabular}

Rezultati navedeni u Tablici 12 upućuju na tri zaključka:

1. Postoji statistički značajan utjecaj dobi na prihvaćanje tvrdnje o brizi za globalnu zaštitu okoliša (zanemarujući stručnu spremu). Ispitanici srednje dobi iskazuju najveću brigu o zaštiti okoliša prilikom kupnje prehrambenih proizvoda $(3,60>3,52$ i 3,60>3,40) budući da je $\mathrm{p}=0,030$. Ispitanici srednje dobi znatno više prihvaćaju tvrdnju B10 u odnosu na ispitanike drugih dobnih skupina, tj. oni kod odabira prehrambenih proizvoda biraju one proizvođače koji brinu o globalnoj zaštiti okoliša.

2. Postoji statistički značajan utjecaj stručne spreme na prihvaćanje tvrdnje o brizi za globalnu zaštitu okoliša (zanemarujući dob). Ispitanici sa završenim preddiplomskim ili diplomskim studijem iskazuju najveću brigu o zaštiti okoliša prigodom kupnje prehrambenih proizvoda $(3,66>3,30$ i 3,66>3,50). Razlika u prihvaćanju tvrdnje B10 u vezi s brigom o zaštiti okoliša između svih triju kategorija stručne spreme statistički je značajna $(\mathrm{p}=0,002)$.

3. Postoji statistički značajna interakcija između dobi i spreme s obzirom na brigu o zaštiti okoliša $(\mathrm{p}=0,004)$.

$\mathrm{Na}$ osnovi navedenih triju zaključaka iz analize varijance može može se zaključiti da druga hipoteza nije potvrđena. 
Četvrta skupina analiza odnosi se na korelaciju svake od 13 zavisnih varijabli s ostalih 12 varijabli. Kako se radi o ordinalnim varijablama izračunati su brojni Spearmanovi koeficijenti korelacije koji su navedeni u Tablici 13.

Tablica 13. Spearmanovi koeficijenti korelacije razmatranih 13 zavisnih varijabli medusobno (matrica koeficijenata korelacije za $N=105$ )*

\begin{tabular}{|c|c|c|c|c|c|c|c|c|c|c|c|c|c|}
\hline Var. & B4 & B5 & B6 & B7 & B8 & B9 & B10 & B11 & B12 & B13 & B14 & B15 & B16 \\
\hline B4 & 1,00 & $\mathbf{0 , 6 4}$ & $\mathbf{0 , 4 7}$ & $\mathbf{0 , 5 4}$ & $\mathbf{0 , 4 3}$ & $\mathbf{0 , 4 7}$ & $\mathbf{0 , 4 5}$ & $\mathbf{0 , 6 0}$ & $\mathbf{0 , 5 0}$ & $\mathbf{0 , 2 2}$ & 0,09 & 0,05 & $\mathbf{0 , 2 7}$ \\
\hline B5 & & 1,00 & $\mathbf{0 , 5 6}$ & $\mathbf{0 , 5 7}$ & $\mathbf{0 , 5 9}$ & $\mathbf{0 , 6 2}$ & $\mathbf{0 , 4 6}$ & $\mathbf{0 , 5 8}$ & $\mathbf{0 , 4 7}$ & $\mathbf{0 , 3 2}$ & $-0,02$ & 0,13 & $\mathbf{0 , 3 4}$ \\
\hline B6 & & & 1,00 & $\mathbf{0 , 6 8}$ & $\mathbf{0 , 4 8}$ & $\mathbf{0 , 3 9}$ & $\mathbf{0 , 4 2}$ & $\mathbf{0 , 6 0}$ & $\mathbf{0 , 5 3}$ & $\mathbf{0 , 3 2}$ & 0,10 & 0,15 & $\mathbf{0 , 3 6}$ \\
\hline B7 & & & 1,00 & $\mathbf{0 , 5 5}$ & $\mathbf{0 , 4 6}$ & $\mathbf{0 , 6 9}$ & $\mathbf{0 , 5 3}$ & $\mathbf{0 , 5 4}$ & $\mathbf{0 , 2 4}$ & $\mathbf{0 , 2 9}$ & $\mathbf{0 , 2 5}$ & $\mathbf{0 , 4 3}$ \\
\hline B8 & & & & & 1,00 & $\mathbf{0 , 6 4}$ & $\mathbf{0 , 5 5}$ & $\mathbf{0 , 5 6}$ & $\mathbf{0 , 3 8}$ & $\mathbf{0 , 3 5}$ & 0,14 & $\mathbf{0 , 2 6}$ & $\mathbf{0 , 2 6}$ \\
\hline B9 & & & & & & 1,00 & $\mathbf{0 , 6 1}$ & $\mathbf{0 , 6 1}$ & $\mathbf{0 , 5 1}$ & $\mathbf{0 , 2 2}$ & 0,16 & $\mathbf{0 , 3 4}$ & $\mathbf{0 , 4 1}$ \\
\hline B10 & & & & & & & 1,00 & $\mathbf{0 , 5 5}$ & $\mathbf{0 , 5 6}$ & 0,15 & $\mathbf{0 , 2 9}$ & 0,16 & $\mathbf{0 , 3 3}$ \\
\hline B11 & & & & & & & & 1,00 & $\mathbf{0 , 5 8}$ & $\mathbf{0 , 3 2}$ & 0,08 & $\mathbf{0 , 2 5}$ & $\mathbf{0 , 3 5}$ \\
\hline B12 & & & & & & & & & 1,00 & $\mathbf{0 , 1 9}$ & $\mathbf{0 , 3 4}$ & $\mathbf{0 , 2 1}$ & $\mathbf{0 , 4 1}$ \\
\hline B13 & & & & & & & & & & 1,00 & $\mathbf{0 , 2 5}$ & $\mathbf{0 , 2 4}$ & $\mathbf{0 , 4 2}$ \\
\hline B14 & & & & & & & & & & & 1,00 & $\mathbf{0 , 4 9}$ & $\mathbf{0 , 4 5}$ \\
\hline B15 & & & & & & & & & & & & 1,00 & $\mathbf{0 , 4 6}$ \\
\hline B16 & & & & & & & & & & & & & 1,00 \\
\hline
\end{tabular}

*Koeficijenti korelacije koji su statistički značajni $(p<0,05)$ podebljano su otisnuti u tablici

Od 78 koeficijenata korelacije u Tablici 13 velika većina je statistički značajnih (67), dok je manje onih koji nisu statistički značajni (11). Nadalje, 77 koeficijenata pokazuje pozitivnu korelaciju dok samo jedan od njih pokazuje negativnu korelaciju. $S$ obzirom na jakost povezanosti onih koeficijenata koji su statistički značajni, postoji:

- 14 koeficijenata koji pokazuju slabu povezanost (između 0,00 i 0,29);

- 28 koeficijenata koji pokazuju slabiju povezanost (između 0,30 i 0,49);

- 25 koeficijenata koji pokazuju osrednju povezanost (između 0,50 i 0,69 ).

U cjelini se može reći da postoji relativno dobra zastupljenost koeficijenata korelacije ranga koji su statistički značajni, ali oni pokazuju pretežno slabiju povezanost. Najveći koeficijenti korelacije su:

- 0,64 - odnosi se na varijablu B8 (govori o nepristranom i korektnom odnosu s poslovnim partnerima) i varijablu B9 (govori o brizi o poštivanju ljudskih prava) i

- 0,68 - odnosi se na varijablu B6 (govori o zapošljavanju lokalnog stanovništva) i varijablu B7 (govori o odgovornom utjecaju na okoliš i prirodne resurse).

Peta je skupina analiza faktorska analiza. Tvrdnje u vezi s DOP-om (B4 do B16) podvrgnute su faktorskoj analizi. Sve su one pozitivno formulirane i na sve su njih odgovori kodirani vrijednostima od 1 (,izrazito se ne slažem“) do 5 („izrazito se slažem“). Prethodno provedeni testovi, Kaiser-Meyer-Olkinova mjera adekvatnosti uzorka $(\mathrm{KMO}=0,84) \mathrm{i}$ Bartlettov test sfericiteta $\left(\chi^{2}=746,959 ; \mathrm{df}=78 ; \mathrm{p}<0,001\right)$, ukazuju da postoje preduvjeti za provedbu faktorske analize. 
Faktorska analiza provedena je tako što je izračunata matrica interkorelacija za 13 tvrdnji (varijabli) iz upitnika, izvršena je ekstrakcija faktora metodom glavnih komponenti, varimax rotacija faktora i izračunati su faktorski bodovi za sve ispitanike (105 potrošača). Prema Kaiser-Guttmanovom kriteriju određivanja značajnosti faktora prva su dva ekstrahirana faktora značajna. Eigen vrijednosti (svojstvene vrijednosti) za prva tri ekstrahirana faktora su 6,00 1,77 i 0,95. Vizualna inspekcija tzv. Scree-plota koji pokazuje odnos broja ekstrahiranih komponenti i veličine svojstvenih vrijednosti (Slika 1) potvrđuje postojanje dvofaktorske strukture. Iz matrice faktorske strukture nakon varimax rotacije (Tablica 13) možemo vidjeti da se tvrdnje B4 do B13 i tvrdnja B16 odnose na ključne elemente DOP-a i opisuju jedan faktor koji je nazvan bitne sastavnice DOP-a. Tvrdnje B14 i B15 odnose se na renome, pozitivan publicitet i pozitivan imidž kompanija te opisuju drugi faktor koji je nazvan ugled kompanije. Ova dva faktora objašnjavaju 59,8\% ukupne analizirane varijance. Oni su se pokazali pouzdanima te njihovi Cronbach alfa koeficijenti pouzdanosti iznose:

- 0,906 za faktor nazvan bitne sastavnice DOP-a

- 0,655 za faktor nazvan ugled kompanije.

U nastavku su iskazani važniji rezultati faktorske analize. Tako je u Tablici 14 matrica faktorske strukture (rotirana), a na kraju je Slika 1 (Scree plot) koja ukazuje na dvije glavne komponente, jer nakon prva dva faktora krivulja prelazi iz strmog u blagi pad.

Tablica 14. Rotirana matrica faktorske strukture (prikazane su sve vrijednosti)

\begin{tabular}{|c|l|c|c|}
\hline & \multicolumn{1}{|c|}{ Varijabla (tvrdnja) } & \multicolumn{2}{c|}{ Faktor } \\
\cline { 2 - 4 } $\begin{array}{c}\text { Oznaka } \\
\text { varijable }\end{array}$ & $\begin{array}{l}\text { Svakom retku u tablici prethodi sljedeći tekst: } \\
\text { „Kod odluke o odabiru i kupnji prehrambenog } \\
\text { proizvoda biram proizvodače... }\end{array}$ & $\mathbf{1}$ & $\mathbf{2}$ \\
\hline B4 & $\ldots$ koji u svom poslovanju primjenjuju elemente DOP-a & $\mathbf{0 , 7 0 8}$ & $-0,350$ \\
\hline B5 & $\ldots$ koji vode brigu o ljudskim resursima & $\mathbf{0 , 7 7 1}$ & $-0,312$ \\
\hline B6 & $\ldots$ koji zapošljavaju lokalno stanovništvo & $\mathbf{0 , 7 0 1}$ & $-0,174$ \\
\hline B7 & $\ldots$ koji odgovorno utječu na okoliš i prirod. resurse & $\mathbf{0 , 8 1 8}$ & $-0,106$ \\
\hline B8 & $\ldots$ koji su nepristrani i korektni s poslovnim partnerima & $\mathbf{0 , 7 6 1}$ & $-0,101$ \\
\hline B9 & $\ldots$ koji brinu o poštivanju ljudskih prava & $\mathbf{0 , 7 8 3}$ & $-0,083$ \\
\hline B10 & $\begin{array}{l}\text {...koji brinu o globalnoj zaštiti okoliša (odgovorno } \\
\text { gospodarenje otpadom,...) }\end{array}$ & $\mathbf{0 , 7 2 6}$ & $-0,081$ \\
\hline B11 & $\begin{array}{l}\text {...koji primjenjuju principe DOP-a - dokaz izbora } \\
\text { kvalitetnog proizvoda }\end{array}$ & $\mathbf{0 , 8 0 1}$ & $-0,143$ \\
\hline B12 & $\begin{array}{l}\text {...koji provode aktivnosti DOP-a - osjećaj osobnog } \\
\text { doprinosa pozitivnom aspektu DOP-a }\end{array}$ & $\mathbf{0 , 7 5 8}$ & $-0,014$ \\
\hline B13 & $\ldots$ koji financijski kontinuirano pozitivno posluju & $\mathbf{0 , 4 5 1}$ & 0,368 \\
\hline B14 & $\ldots$ koji su renomirani i s pozitivnim publicitetom & 0,355 & $\mathbf{0 , 7 2 1}$ \\
\hline B15 & $\ldots$ koji imaju pozitivan imidž & 0,390 & $\mathbf{0 , 7 0 1}$ \\
\hline B16 & $\ldots$ koji su poželjan poslodavac & $\mathbf{0 , 5 7 4}$ & 0,569 \\
\hline
\end{tabular}




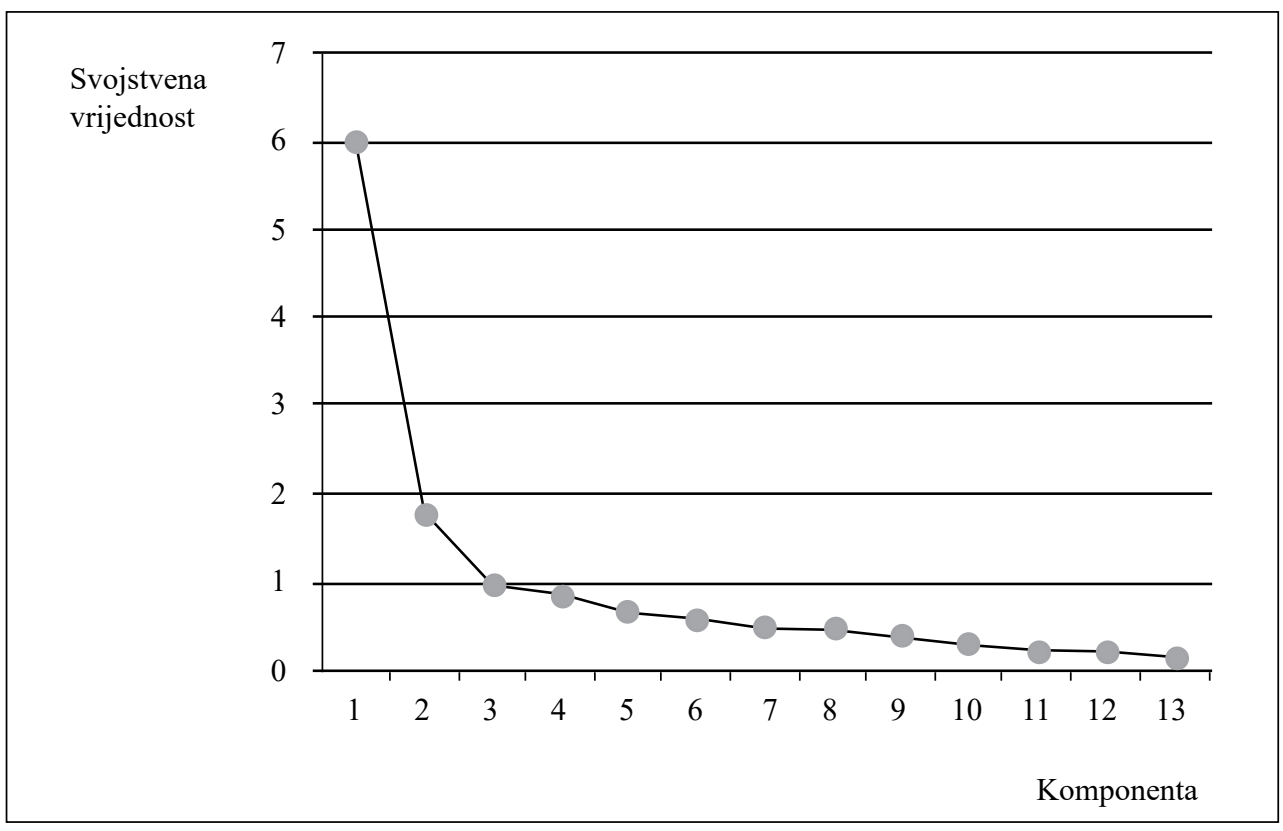

Slika 1. Scree plot za 13 varijabli (B4 do B16) koje su obuhvaćene faktorskom analizom

Šesta je skupina analiza klaster analiza. Metodom nehijerarhijskog klasteriranja ( $k$-Means Cluster), kroz četiri iteracije, skupina od 105 potrošača razdvojena je u tri podskupine, tri klastera. Osnovu za grupiranje potrošača činilo je pet odabranih ordinalnih varijabli (svaka s mogućim vrijednostima od 1, 2 i 3) koje su navedene u Tablici 15 Podjela na tri klastera navedena je u Tablici 16, a grafički je prikazana na Slici 2.

Tablica 15. Varijable korištene za klasteriranje potrošača i konačni klaster centri pojedinih klastera (deblje su otisnuti ekstremni klaster centri od 1 i 3 )

\begin{tabular}{|c|l|c|c|c|c|}
\hline Rbr. & \multicolumn{1}{|c|}{ Varijable korištene kod klasteriranja } & Vrsta varijable & Kl.1 & K1.2 & K1.3 \\
\hline 1. & Dob potrošača $(1=$ mlađa, $2=$ srednja 3 = starija) & ordinalna & 2 & 2 & 2 \\
\hline 2. & $\begin{array}{l}\text { Stručna sprema potrošača }(1=\text { OŠ i SŠ, } 2=\text { dodipl. } \\
\text { i diplomski studij, 3 = postdipl. i doktorski studij) }\end{array}$ & ordinalna & 1 & 2 & 2 \\
\hline 3. & B7 (1=ne slažem se, 2=neodlučan, 3=slažem se $)$ & ordinalna & 3 & 3 & 2 \\
\hline 4. & B10 (1=ne slažem se, 2=neodlučan, 3=slažem se) & ordinalna & 3 & 3 & 2 \\
\hline 5. & B12 (1=ne slažem se, 2=neodlučan, 3=slažem se) & ordinalna & 3 & 3 & 2 \\
\hline
\end{tabular}

Moguće je provjeriti koliko uspješno ovi centri separiraju pojedine klastere međusobno na pojedinim varijablama. Od više metoda provjere korištena je analiza varijance između klastera po svakoj varijabli, čime ispitujemo omjer varijance između klastera i unutar klastera. Analiza varijance za svaku od varijabli korištenih kod klasteriranja dala je $\mathrm{p}<0,001$ pa je: 
Dob potrošača

Sprema potrošača

B7

B10

$\mathrm{B} 12$

$$
\begin{array}{ll}
F=12,308 & \mathrm{p}<0,001 \\
\mathrm{~F}=19,795 & \mathrm{p}<0,001 \\
\mathrm{~F}=59,164 & \mathrm{p}<0,001 \\
\mathrm{~F}=75,142 & \mathrm{p}<0,001 \\
\mathrm{~F}=67,476 & \mathrm{p}<0,001
\end{array}
$$

Prema tome, razlike između klastera su statistički visoko značajne za svaku pojedinu od pet varijabli korištenih kod klasteriranja. Dakle, postupak klasterizacije potrošača uspješno je proveo njihovu homogenizaciju na temelju multidimenzionalnog načela, tj. na temelju relevantnih varijabli.

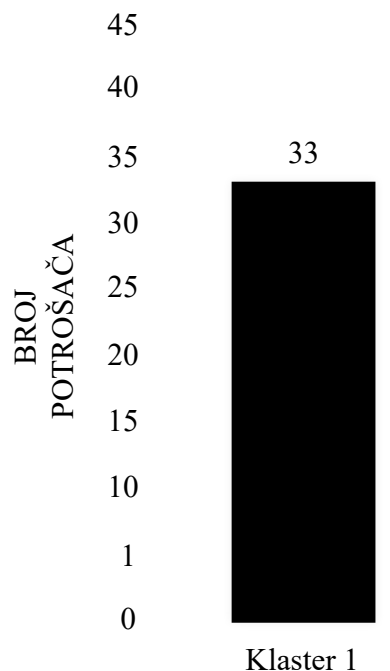

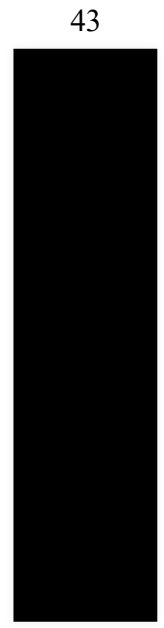

Klaster 2
29

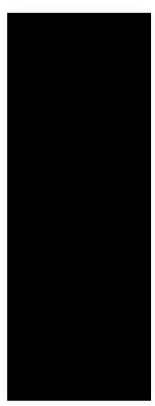

Klaster 3

Slika 2. Grafički prikaz broja potrošǎ́a svrstanih u pojedine klastere

Tablica 16. Podjela potrošača na klastere prema izabranih pet varijabli

\begin{tabular}{|c|c|c|}
\hline Klasteri & Broj potrošača & \% potrošača \\
\hline 1 & 33 & 31 \\
\hline 2 & 43 & 41 \\
\hline 3 & 29 & 28 \\
\hline Ukupno & 105 & 100 \\
\hline
\end{tabular}

Tipičan potrošač srednje je dobi (36-55 g.), dodiplomskog ili diplomskog studija i slaže se s tvrdnjama B7, B10 i B12. Ovakav opis treba usporediti s opisom potrošača u 
pojedinim klasterima. U Tablici 15 podebljano su otisnuti karakteristični (ekstremni) klaster centri (vrijednosti 1 ili 3). Pomoću njih i kontingencijskih tablica u kojima je stavljen u odnos broj klastera i pojedina od pet klasteriziranih varijabli mogu se opisati karakteristike pojedinih klastera:

Klaster $1 \mathrm{ima} 31 \%$ potrošača koji se od drugih klastera razlikuju po sljedećim karakteristikama: ovi su potrošači uglavnom srednje, ali i starije dobi, pretežno su sa završenom osnovnom ili srednjom školom, ali i dodiplomskim i diplomskim studijem, uglavnom prihvaćaju tvrdnju B7, pretežno prihvaćaju tvrdnju B10, ali ih je dosta i indiferentnih te najviše prihvaćaju tvrdnju B12.

Klaster 2 obuhvaća 41\% potrošača sa sljedećim karakteristikama: uglavnom su srednje, ali i mlađe dobi, većinom sa završenim dodiplomskim ili diplomskim studijem, velika većina ih prihvaća tvrdnju B7, isključivo prihvaćaju tvrdnju B10, dok tvrdnju B10 skoro svi prihvaćaju.

Klaster 3 obuhvaća najmanje potrošača (njih 28\%) sljedećih karakteristika: uglavnom su srednje dobi, većinom su završili dodiplomski ili diplomski studij, uglavnom su indiferentni prema tvrdnji B7 ali među njima je i dosta potrošača koji ne prihvaćaju te tvrdnje i pretežno su indiferentni kod tvrdnje B10 i kod tvrdnje B12.

\section{ZAKLJUČAK}

Društveno odgovorno poslovanje od velike je važnosti za prehrambene kompanije jer ovaj sektor ima snažan utjecaj i veliku ovisnost o gospodarstvu, okolišu i društvu općenito. Odgovorno ponašanje kompanija može utjecati na brojne pozitivne ishode u vezi $s$ potrošačima, kao što su njihova lojalnost, pozitivan stav spram određenih proizvoda, zatim pozitivan imidž kompanije i njezinih proizvoda te u konačnici pozitivan utjecaj na namjeru kupnje.

Istraživanjem je utvrđeno da kod odluke o odabiru i kupnji prehrambenih proizvoda potrošači biraju proizvođače koji odgovorno utječu na okoliš i prirodne resurse, koji brinu o globalnoj zaštiti okoliša i koji provode aktivnosti DOP-a, jer tako stječu osjećaj osobnog doprinosa pozitivnom aspektu DOP-a. Time su utvrđena tri najznačajnija elementa DOP-a prehrambenih kompanija što je bio jedan od ciljeva istraživanja. Nadalje, percepcija potrošača u vezi s aktivnostima prehrambenih kompanija u vezi $s$ DOP-om podjednako su zastupljena među potrošačima različitog spola, različite dobi odnosno različite stručne spreme. Briga o globalnoj zaštiti okoliša kao jednoj od glavnih odrednica pojma društveno odgovornog poslovanja statistički se značajno razlikuje kod potrošača prehrambenih proizvoda koji su različite dobi te različite stručne spreme. Navedene spoznaje mogu koristiti proizvođačima prehrambenih proizvoda u definiranju komparativnih prednosti u odnosu na konkurenciju u namjeri diferencijacije i doprinosa povećanoj vrijednosti za potrošače, ali i šire.

Reakcija potrošača na odgovorno ponašanje kompanije važan je poticaj za kompanije da se uključe u definiranje i provođenje aktivnosti DOP-a. Budući da prehrambene kompanije posluju na visoko zasićenim tržištima, provođenje strategije diferencijacije putem 
DOP-a može utjecati na povećanje konkurentnosti kompanija. Koliko god bi DOP mogao poslužiti kao zaštita od rizika u vezi sa sigurnosti hrane, okoliša ili socijalnih problema, reputacija odgovornog ponašanja može biti posebno važna za ugled prehrambenih kompanija, što predstavlja ključ uspješnog odnosno profitabilnog poslovanja. Dobivene spoznaje temeljem provedenog istraživanja mogu poslužiti kao osnova za buduća istraživanja najznačajnijih elemenata društveno odgovornog poslovanja prehrambenih kompanija u Republici Hrvatskoj, za što se preporučuje provedba na većem slučajnom uzorku što bi pružilo reprezentativnije rezultate.

\section{LITERATURA}

Bačun, D., Matešić M. i Omazić, M. A. (2012). Leksikon održivog razvoja. Zagreb: Hrvatski poslovni savjet za održivi razvoj.

Bagić, A., Škrabalo i M., Narančić, L. (2006). Društvena odgovornost poduzeća u Hrvatskoj. Zagreb: AED (Academy for Educational Devolpment).

Bagić, A., Škrabalo i M., Narančić, L. (2004). Pregled društvene odgovornosti poduzeća u Hrvatskoj. Zagreb: AED (Academy for Educational Devolpment).

Boccia, F. i Covino, D. (2018). Corporate and Consumer Social Responsibility in the Italian Food Market System. U: Muenstermann, I. (ur.), Social Responsibility. London: IntechOpen. URL: https://www.intechopen.com/books/social-responsibility/ corporate-and-consumer-social-responsibility-in-the-italian-food-market-system (24.09.2019.)

Boumediene, O. i Houda, Y. N. E. (2018). Corporate Social Responsibility in Food and Beverage Industry: An Analysis Study of Soft Drinks Sector in Algeria. European Scientific Journal, 14(1): 190-207.

Buble, M. (2009). Menadžment. Split: Ekonomski fakultet. Sveučilište u Splitu.

Carroll, A. B. (1999). Corporate social responsibility: Evolution of a definitional construct. Business \& Society 38(3): 268-295.

Carroll, A. B. (1991). The pyramid of corporate social responsibility: Toward the moral management of organisational stakeholders. Business Horizons, 34(4): 39-48.

Cartland, A. (2015). Who Works in CSR? Staffing and Recruitment in CSR. U: Pohl, M. i Tolhurst, N. (ur.), Responsible Business: How to Manage a CSR Strategy Successfully (str. 43-62). Hoboken, NJ: John Wiley \& Sons.

Cerjan-Letica, G. (2010). Piramida profesionalne i poslovne odgovornosti u hrvatskoj stomatologiji. Acta Stomatologica Croatica, 44 (2): 101-109.

Cragg, W., Schwartz, M. S. i Weitzner, D. (2017). Corporate social responsibility. London: Routledge.

Daskalopoulou, I. (2019). The Market for CSR Practices: Issues and Challenges for the Food Sector. U: Daskalopoulou, I. (ur.), Corporate Social Responsibility: Concepts, Methodologies, Tools, and Applications (str. 173-186). Hershey, PA: IGI Global.

Donaldson, T. i Preston, L. (1995). The stakeholder theory of the corporation: concepts, evidence, and implications. Academy of Management Review, 20 (1): 65-91. 
Fisher, J. (2004). Social Responsibility and Ethics: Clarifying the Concepts, Journal of Business Ethics, 52(4): 391-400.

Europska komisija (2001). Green Paper: Promoting a European Framework for Corporate Social Responsibility. DOC/01/9, Bruxelles, 18. srpnja 2001. URL: https:// ec.europa.eu/commission/presscorner/api/files/document/print/en/doc_01_9/ DOC_01_9_EN.pdf (03.10.2019.)

Glavočević, A. i Radman-Peša, A. (2013). Društveno odgovorno poslovanje i CRM kao način integriranja društvene odgovornosti u marketinške aktivnosti. Oeconomica Jadertina, 3(2): 28-49.

Heikkurinen, P. i Forsman-Hugg, S. (2011). Strategic Corporate Responsibility in the Food Chain. Corporate Social Responsibility and Environmental Management, 18(5): 306-316.

Hopkins, M. (2006). What is Corporate Social Responsibility all about. Journal of Public Affairs, 6(3-4): 176-184.

Kesić, T. (2006). Ponašanje potrošača. Zagreb: Opinio.

Kotler, P. i Lee, N. (2009). Društveno odgovorno poslovanje - suvremena teorija i najbolja praksa. Zagreb: M.E.P

Lombardi, A., Caracciolo, F., Cembalo i L. i Lerro, M. (2015). How Does Corporate Social Responsibility in the Food Industry Matter? New Medit, 14(3): 2-9.

Matešić, M., Pavlović, D. i Bartoluci, D. (2015). Društveno odgovorno poslovanje. Zagreb: VPŠ Libertas.

McIntyre, J. R., Ivanaj i S., Ivanaj, V. (2018). CSR and climate change implications for multinational enterprises. Cheltenham: Edward Elgar Publishing.

McWilliams, A. i Siegel, D. (2001). Corporate social responsibility: a theory of the firm perspective. Academy of Management Review, 26(1): 117-127

Pathak, Y. (2011). Handbook of Nutraceuticals Volume II: Scale-Up, Processing and Automation. Boca Raton, FL: CRC Press.

Poljak, P., Duboković, I. i Lenardić, M. (2013). Razlozi i preduvjeti za sustavnu implementaciju DOP-a u poduzetničke tvrtke - primjena iskustava velikog poslovnog sustava. Učenje za poduzetništvo, 3(2): 178-186.

Quien, M. (2012). Društveno odgovorno poslovanje kao konkurentna prednost: analiza ciljeva najuspješnijih tvrtki u Hrvatskoj. Učenje za poduzetništvo, 2(1): 303-307.

Reichert, R. (2016). Big Data and CSR Communication. U: Diehl, S., Karmasin, M., Mueller, B., Terlutter, R. i Weder, F. (ur.), Handbook of Integrated CSR Communication (str. 211-224). Cham: Springer International Publishing.

Šiljković, Ž. (2000). Uloga geografske znanosti u uvođenju ekološke poljoprivrede u geografski prostor Hrvatske. Socijalna ekologija. 9(4): 275-285

Vrdoljak Raguž, I. (2014). Društveno odgovorno poslovanje i hrvatska gospodarska praksa. Oeconomica Jadertina, 4(1): 40-58. 


\title{
KEY ELEMENTS OF CORPORATE SOCIAL RESPONSIBILITY OF FOOD COMPANIES IN CROATIA
}

\begin{abstract}
Romana Zlatar-Vulić
Abstract

There is increased interest in corporate social responsibility (CSR) in Croatia. Corporate social responsibility includes economic, environmental and social responsibility and businesses increasingly recognize its importance. Regardless of the type of business, Croatian companies have started implementing corporate social responsibility in business strategies in order to develop sustainable practices in their businesses and communities. Consumers are also increasingly aware of and interested in corporate social responsibility. Existing research in Croatia has not examined social responsibility of food companies from the perspective of Croatian consumers. The aim of our research was to investigate social responsibility of Croatian food companies from the perspective of Croatian consumers and to determine which elements of social responsibility influence their decision to buy from these companies. Our research was conducted in October and November 2017 by administering an online questionnaire on a sample of 105 respondents, mostly from the Northwest Croatia. The results were statistically analyzed and revealed that consumers' decisions to buy certain food company's products are least influenced by whether these companies have positive cash flow and most influenced by the company's socially responsible activities. This is because consumers indirectly feel part of the company's positive CSR and its responsible behavior toward the environment, natural resources and global environment in general. The research revealed statistically significant differences between consumers' age and level of education and the influence that the company's care for the global environment had on their decision to buy that company's products. Caring for the global environment was most important to middle age consumers with completed higher education.
\end{abstract}

Key words: corporate social responsibility, consumer decision, food products

\section{DIE WICHTIGSTEN ELEMENTE DES SOZIAL VERANTWORTUNGSVOLLEN WIRTSCHAFTENS DER NAHRUNGSMITTELUNTERNEHMEN IN DER REPUBLIK KROATIEN}

Romana Zlatar-Vulić

\section{Zusammenfassung}

Kroatien verzeichnet eine kontinuierliche Zunahme des Interesses am Konzept des „sozial verantwortungsvollen Wirtschaftens". Das Konzept des sozial verantwortungsvollen Wirtschaftens bezieht eine ökonomische, ökologische und soziale Verantwortung ein und wird als wichtiger Faktor bei immer mehr Wirtschaftssubjekten gesehen. Ungeachtet des Tätigkeitsbereichs haben kroatische Unternehmen die Wichtigkeit der Einführung eines sozial verantwortungsvollen Wirtschaftens in die eigene Strategie zwecks Schaffung eines nachhaltigen Wirtschaftens und einer nachhaltigen Gemeinschaft erkannt. Das sozial verantwortungsvolle Wirtschaften haben auch Verbraucher erkannt, deshalb wird auch bei ihnen ein immer größeres Interesse an der sozialen Verantwortung von Geschäftssubjekten verzeichnet. Bisherige Forschung hat sich nicht damit beschäftigt, wie kroatische Verbraucher das sozial verantwortungsvolle Wirtschaften der Nahrungsmittelunternehmen auffassen. Deshalb versuchen wir in dieser Arbeit eine Einsicht ins sozial verantwortungsvolles Wirtschaften von Nahrungsmittelunternehmen aus der Sicht der Verbraucher zu gewähren, sowie Angaben darüber, welcher Bereich des sozial verantwortungsvollen Wirtschaftens beim Kauf von Nahrungsmitteln für Käufer am wichtigsten ist. Die Forschung des sozial verantwortungsvollen Wirtschaftens und Kaufverhaltens beim Kaufvon Lebensmitteln umfasste 105 Befragte, vorwiegend aus dem Raum des kroatischen Nordwestens. Die Forschung wurde im Oktober und November 2017 mit einem online 
Fragebogen durchgeführt. Die Ergebnisse wurden statistisch bearbeitet. Die Ergebnisse haben gezeigt, dass Verbraucher beim Kaufvon Ernährungsartikeln den wenigsten Wert auf die positive finanzielle Geschäftstätigkeit von Nahrungsmittelunternehmen legen, während sie den größten Wert auf sozial verantwortungsvolle Aktivitäten von Unternehmen legen, denn so haben sie das Gehfühl, einen eigenen Beitrag dem positiven Aspekt des sozial verantwortungsvollens Wirtschaftens, dem verantwortungsvollen Verhalten der Unternehmen der Umwelt und en Ressourcen gegenüber und der Fürsorge von Unternehmen für die globale Umwelt zu leisten. Die Forschung hat gezeigt, dass ein statistisch relevanter Unterschied hinsichtlich des Alters und der Schulbildung der Verbraucher besteht, wenn die Fürsorge der Unternehmen für die globale Umwelt die Kaufentscheidung beeinflußt Fürsorge für die globale Umwelt ist den Verbrauchern mittleren Lebensalters, sowie denen, die ein Studium abgeschlossen haben, am wichtigsten.

Schlüsselwörter: sozial verantwortungsvolles Wirtschaften, Kaufentscheidung, Ernährungsartikel 